\title{
DUPLEX SONOGRAPHY STUDY IN SCHISTOSOMIASIS PORTAL HYPERTENSION: characterization of patients with and without a history of variceal bleeding
}

\author{
Severino Marcos Borba de ARRUDA 1 , Victorino Spinelli Toscano BARRET0 ${ }^{1}$ and \\ Fernando José do AMARAL²
}

\begin{abstract}
Background - Presinusoidal portal hypertension with frequent episodes of upper gastrointestinal variceal bleeding are hallmarks of hepatosplenic Manson's schistosomiasis; a clinical form that affects about 5\% of Brazilians who are infected by Schistosoma mansoni. Aims - To evaluate duplex sonography findings in patients with hepatosplenic Manson's schistosomiasis with and without upper gastrointestinal variceal hemorrhage. Methods - A cross-sectional study was performed whereby 27 consecutive patients with hepatosplenic Manson's schistosomiasis were divided into two groups: group I (six men and six women; mean age 48.7 years) with a past history of bleeding and group II (four men and eight women; mean age 44.7 years) without a past history of upper gastrointestinal bleeding, underwent duplex sonography examination. All patients underwent the same upper gastrointestinal endoscopy and laboratory examinations. Those with signs of mixed chronic liver disease or portal vein thrombosis (three cases) were excluded. Results - Group I showed significantly higher mean portal vein flow velocity than group II $(26.36 \mathrm{~cm} / \mathrm{s}$ vs $17.15 \mathrm{~cm} / \mathrm{sec})$. Although, as a whole it was not significant in all forms of collateral vessels ( $83 \%$ vs $100 \%)$, there was a significantly higher frequency of splenorenal collateral circulation type in group II compared with group I ( $17 \%$ vs $67 \%)$. The congestion index of the portal vein was significantly lower in group I than in group II $(0.057 \mathrm{~cm} \mathrm{vs} 0.073 \mathrm{~cm} / \mathrm{sec})$. Conclusion - Our duplex sonography findings in hepatosplenic Manson's schistosomiasis support the idea that schistosomotic portal hypertension is strongly influenced by overflow status, and that collateral circulation seems to play an important role in hemodynamic behavior.
\end{abstract}

HEADINGS - Hypertension, portal. Schistosomiasis mansoni. Ultrasonography, Doppler.

\section{INTRODUCTION}

Pressure in the portal vein, as in any other hydrostatic system follows the general rule defined by the equation: $\mathrm{p}=\mathrm{f} \times \mathrm{r}$ (where $\mathrm{p}=$ pressure, $\mathrm{f}=$ flow and $\mathrm{r}=$ resistance). Portal hypertension therefore may result from an increase in portal blood flow (Banti's hypothesis) and/or an increase in resistance to the flow $^{(3,17)}$.

In cirrhosis the increase in portal pressure is clearly associated with an increase in outflow resistance and, indeed, portal blood flow and flow velocity tend to decrease as the disease gets worse and portal pressure builds up ${ }^{(8,23,25,29,34,35,36,38)}$.

In contrast, portal hypertension that sometimes occurs in association with splenomegaly due to myeloid metaplasia seems to be solely dependent on increased splenoportal venous inflow ${ }^{(19,20,37)}$.

Hepatosplenic schistosomiasis is a unique form of chronic fibrosing liver disease characterized by significant portal fibrosis with a preserved lobular parenchyma and a presinusoidal inflow block $^{(9,10,12)}$, generating a presinusoidal portal hypertension state, as demonstrated by COUTINHO ${ }^{(5,6)}$ in our Department early in 1960s.

Moreover, probably as a result of chronic immunological stimulation due to long standing parasitosis, we often see disproportionate splenomegaly, which on pathological examination discloses significant hyperplastic changes besides the "congestive" findings common to all forms of portal hypertension, thus setting the stage for an increase in splenic and subsequently portal blood flow. This would add to the already increased portal pressure caused by the above mentioned presinusoidal block ${ }^{(10)}$.

Later in 1990 SARIN et al. ${ }^{(33)}$ published data on portal hypertension in mice chronically infected by Schistosoma mansoni which became the animal model for schistosomotic portal hypertension. In their study the portal venous flow in infected specimens was $61 \%$ higher than in the healthy animals.

'Department of Internal Medicine, Gastroenterology and Endoscopy Division, Federal University of Pernambuco; ${ }^{2}$ Ultrasound and Radiology Division, Hospital "Barão de Lucena", Recife, PE, Brazil

Correspondence: Dr. Severino Marcos Borba de Arruda - Departamento de Medicina Clínica - UFPE - Av. Prof. Moraes Rego, s/n - Cidade Universitária - 50670-901 -Recife, PE, Brazil. E-mail: smbarruda@uol.com.br 
Indeed, there is now enough evidence from angiographic ${ }^{(15,22,24)}$ and radionuclide scanning ${ }^{(2)}$ studies to support the view that increased splenoportal blood flow is a major component of portal hypertension in hepatosplenic schistosomiasis. This is likely to be the pathophysiological basis for the success of splenectomy as first line surgical therapy for portal hypertension related to schistosomiasis ${ }^{(30)}$, and stands in sharp contrast to cirrhosis, where only shunting procedures effectively lower the portal pressure.

Since patients in endemic areas often present mixed forms of liver disease due to the frequent association of schistosomiasis with chronic hepatitis, particularly due to $\mathrm{HCV}$ and $\mathrm{HBV}^{(27,28)}$, knowledge of these patterns with a more precise characterization of portal hypertension may be critical to the clinician caring for them, who may consider surgical therapy as part of their management.

This cross-sectional study was therefore performed to identify variable(s) in duplex ultrasound which could be helpful in predicting the risk of variceal hemorrhage in patients with schistosomiasis and portal hypertension, and for the first time evaluating if "the congestion index of portal vein", described by MORIYASU et al. ${ }^{(23)}$, would be able to differentiate cirrhotic (associated with low portal blood flow) from schistosomotic (associated with portal overflow) patients with portal hypertension.

We assessed liver and spleen morphology as well as the hemodynamic parameters in portal and splenic veins in the hepatosplenic schistosomiasis clinical form with and without a past history of esophageal variceal bleeding. We chose duplex sonography because it is a noninvasive method and has already been validated in cirrhotics and normal subjects ${ }^{(1,18)}$.

\section{METHODS}

\section{Subjects}

We studied 27 consecutive adult patients with mansonic hepatosplenic schistosomiasis recruited from the gastroenterology outpatient unit of the Federal University Hospital of Pernambuco, Recife, PE (Northeast of Brazil), between February 1995 and March 1996. Three patients were excluded due to ultrasound evidence of portal vein thrombosis. The remaining 24 were divided into two groups of 12 patients each. Group I (gI), six males and six females with mean age 48.7 years (range 2666 years) with a past history of variceal bleeding. group II (gII), four males and eight females with mean age 44.7 years (range 18-69 years) with no history of bleeding.

\section{Inclusion criteria}

Patients were included if they came from a known endemic area for schistosomiasis and had a positive stool examination for schistosoma eggs, hepatosplenomegaly on physical examination, normal liver blood tests (alanine/aspartate aminotransferases, serum albumin and prothrombin time), endoscopic diagnosis of medium (F2) or large (F3) size esophageal varices according to the criteria of The Japanese Research Society for Portal Hypertension - JRSPH ${ }^{(14)}$, and grade II or III periportal fibrosis on ultrasound according to the criteria of the World Health Organization (WHO) - Cairo, Egypt, 1991(39).

\section{Exclusion criteria}

Ultrasound findings suggestive of cirrhosis, stigmata of chronic liver disease (spiders, palmar erythema etc) on physical examination, past or present history of ascites, evidence of thrombosis or cavernous transformation of portal vein, clinical signs of cardiac failure and any previous history of sclerotherapy, banding or surgical ligation of varices, and splenectomy.

\section{Methods}

a) Ultrasound: the patient's left and right lobe longitudinal liver diameters, portal and splenic vein diameters and longitudinal spleen diameter were measured by conventional ultrasound examination according to standard WHO protocol ${ }^{(39)}$ using an Aloka 500 device with a $3.5 \mathrm{MHz}$ convex probe. Portal and splenic blood flow velocity $(\mathrm{cm} / \mathrm{s})$, collateral veins and congestion index were determined by Doppler ultrasound examination with a Philips P700 machine using 2.0, 3.75 and 5.0 MHz probes according to PATRIQUIN et al. ${ }^{(26)}$ and MORIYASU et al. ${ }^{(23)}$ criteria. Congestion index $(\mathrm{cm} \mathrm{x} \mathrm{sec})=$ portal vein cross-sectional area $\left(\mathrm{cm}^{2}\right)$ divided by mean portal vein flow velocity $(\mathrm{cm} / \mathrm{sec})$. All patients were studied at rest, fasting and during quiet respiration.

b) Endoscopy: upper gastrointestinal endoscopy was performed according to standard methods using an Olympus EVIS 100 video system (Japan). Varices were classified according to $\mathrm{JRSPH}^{(14)}$ criteria.

\section{Study design and statistical analysis}

This is a cross-sectional study where the congestion index of portal vein and other duplex sonography findings were studied in bleeding and non-bleeding patients with schistosomotic portal hypertension. Data were expressed as means \pm standard deviation (SD) and frequency (absolute and percentage values). Comparisons between groups were made using the non-parametric Mann-Whitney test and Fisher's exact test. Also, comparisons were made using the Chi-square test with Yates correction if criteria for correction were met. The significance level was 5\%.

\section{RESULTS}

Patients with and without a past history of gastrointestinal hemorrhage were homogeneous with respect to age, sex, periportal fibrosis and esophageal variceal diameters (Table 1). However, patients without bleeding had a larger mean splenic vein $(1.3$ $\pm 0.34 \mathrm{~cm}$ vs $1.1 \pm 0.30 \mathrm{~cm} ; P>0.05)$ and larger longitudinal spleen diameters $(19.2 \pm 3.07 \mathrm{~cm}$ vs $17.1 \pm 2.18 \mathrm{~cm} ; P>0.05)$ than patients with hemorrhage, although the differences were not significant (Table 2).

The portal blood flow velocity $(26.4 \mathrm{~cm} / \mathrm{s}$ vs $17.2 \mathrm{~cm} / \mathrm{s}$; $P<0.05)$ was significant, while splenic blood flow velocity $(32.1 \mathrm{~cm} / \mathrm{s}$ vs $28.1 \mathrm{~cm} / \mathrm{s} ; P<0.05)$ was not, and they were higher in the bleeding than in the non-bleeding group (Table 3 ). 
Overall, collateral circulation was found more frequently in the non-bleeding group, although this difference was not significant $(100 \%$ vs $83 \% ; P=0.239)$. Moreover, the splenorenal vein was more often present in this group than in the bleeding group (67\% vs $17 \% ; P=0.038)$. Similarly, but not statistically significant, the frequency of the left gastric vein was much higher in the group of non-bleeders ( $92 \%$ vs $67 \% ; P=0.316)$ (Table 4$)$.

TABLE 1. Demographyc data, periportal fibrosis grade and variceal calipters

\begin{tabular}{|c|c|c|c|}
\hline & Group I & Group II & $P$ value and test \\
\hline \multicolumn{4}{|l|}{ Age } \\
\hline range & $(26-66)$ & $(18-69)$ & Mann Whitney \\
\hline male & 6 & 4 & $P=0.678$ \\
\hline female & 6 & 8 & chi-square w/y \\
\hline \multicolumn{4}{|c|}{ Fibrosis grade ${ }^{*}$} \\
\hline \multicolumn{4}{|c|}{ Varices size ${ }^{* *}$} \\
\hline F2 & 3 & 6 & $P=0.399$ \\
\hline F3 & 9 & 6 & chi-square w/y \\
\hline
\end{tabular}

${ }^{*}$ Moderate (GII) and severe (GIII) fibrosis grades

${ }^{* *}$ Medium (F2) and large (F3) variceal sizes

TABLE 2. Left and right hepatic lobes, portal and splenic veins, and spleen longitidinal diameters

\begin{tabular}{lcccc}
\hline Diameter & Group I & Group II & & \\
\hline$(\mathrm{cm} \pm \mathrm{SD})^{*}$ & $(\mathrm{n}=12)$ & $(\mathrm{n}=12)$ & Test** & $P$ value \\
Left hep lobe & $8.99 \pm 1.92$ & $8.7 \pm 2.30$ & $\mathrm{Z}=-0.693$ & $P>0.05$ \\
Right hep lobe & $11.3 \pm 1.83$ & $10.8 \pm 1.94$ & $\mathrm{Z}=-1.039$ & $P>0.05$ \\
Portal vein & $1.36 \pm 0.25$ & $1.36 \pm 0.33$ & $\mathrm{Z}=+1.791$ & $P>0.05$ \\
Splenic vein & $1.1 \pm 0.30$ & $1.3 \pm 0.34$ & $\mathrm{Z}=-0.375$ & $P>0.05$ \\
Spleen (long) & $17.1 \pm 2.18$ & $19.2 \pm 3.07$ & $\mathrm{Z}=-1.963$ & $P>0.05$ \\
\hline
\end{tabular}

* Values expressed as mean \pm standard deviation

** Non-parametric Mann-Whitney test

TABLE 3. Doppler duplex findings

\begin{tabular}{|c|c|c|c|c|c|}
\hline \multirow[t]{2}{*}{ Groups } & \multicolumn{2}{|c|}{ Portal vein } & \multicolumn{2}{|c|}{ Splenic vein } & \multirow{2}{*}{$\begin{array}{c}\text { Congestion index } \\
(\mathrm{cm} \times \mathrm{sec})\end{array}$} \\
\hline & $\begin{array}{l}\text { diameter } \\
(\mathrm{cm})\end{array}$ & $\begin{array}{l}\text { flow velocity } \\
(\mathrm{cm} / \mathrm{sec})\end{array}$ & $\begin{array}{l}\text { diameter } \\
(\mathrm{cm})\end{array}$ & $\begin{array}{l}\text { flow velocity } \\
\qquad(\mathrm{cm} / \mathrm{sec})\end{array}$ & \\
\hline HSS* w (GI) & $1.36 \pm 0.25$ & $26.4 \pm 10.7$ & $1.1 \pm 0.30$ & $32.1 \pm 11.5$ & $0.057 \pm 0.032$ \\
\hline HSS* wt (GII) & $1.36 \pm 0.33$ & $17.1 \pm 3.75$ & $1.3 \pm 0.34$ & $28.1 \pm 13.4$ & $0.073 \pm 0.041$ \\
\hline$P$ value & $\mathrm{ns} * *$ & $\mathrm{P}<0.05$ & ns & ns & $\mathrm{P}<0.05$ \\
\hline
\end{tabular}

HSS: hepatosplenic schistosomiasis with (w) and without (wt) hemorrhage
$* \star$ ns: not significant

TABLE 4. Types and frequences of collateral vessels

\begin{tabular}{|c|c|c|c|}
\hline Types & $\begin{array}{c}\text { Group I } \\
\mathrm{n}(\%)\end{array}$ & $\begin{array}{c}\text { Group II } \\
\text { n }(\%)\end{array}$ & $P$ value and test \\
\hline \multirow[t]{2}{*}{ Left gastric vein } & $8 / 12(67 \%)$ & $11 / 12(92 \%)$ & $P=0.316(\mathrm{~ns})$ \\
\hline & & & Fisher's exact test \\
\hline \multirow[t]{2}{*}{ Splenorenal vein } & $2 / 12(17 \%)$ & $8 / 12(67 \%)$ & $P=0.038$ \\
\hline & & & Fisher's exact test \\
\hline \multirow[t]{2}{*}{ Umbilical vein } & $1 / 12(8 \%)$ & 0 & $P=1.0(\mathrm{~ns})$ \\
\hline & & & Fisher's exact test \\
\hline \multirow[t]{2}{*}{ Gallblader veins } & $1 / 12(8 \%)$ & 0 & $P=1.0(\mathrm{~ns})$ \\
\hline & & & Fisher's exact test \\
\hline \multirow[t]{2}{*}{ Periportal veins } & 0 & $1 / 12(8 \%)$ & $P=1.0(\mathrm{~ns})$ \\
\hline & & & Fisher's exact test \\
\hline \multirow[t]{2}{*}{ All patients } & $10 / 12(83 \%)$ & $12 / 12(100 \%)$ & $P=0.239(\mathrm{~ns})$ \\
\hline & & & Fisher's exact test \\
\hline
\end{tabular}

ns: not significant 


\section{DISCUSSION}

In 1986 MORIYASU et al. ${ }^{(23)}$ described a simple method which they called "Congestion Index of the Portal Vein" that proved to be effective in separating bleeders from non-bleeders in a group of cirrhotics calculated by the formula: confidence interval $(\mathbf{C I})(\mathrm{cm} \mathrm{x} \mathrm{sec})=$ cross-sectional area $\left(\mathrm{cm}^{2}\right)$ divided by the blood flow velocity $(\mathrm{cm} / \mathrm{sec})$ of the portal vein.

The significance of the congestion index for detection of portal hypertension has been progressively well demonstrated as being the most sensitive when compared with other Doppler and conventional sonography parameters ${ }^{(11,23,35)}$. Moreover, the CI has also been shown to be significantly correlated with clinical, biochemical and endoscopic data in portal hypertension $^{(4,13,23,35,36)}$.

We then evaluated if the CI would be equally as effective in a group of patients with hepatosplenic mansonic schistosomiasis. Our results were interesting not only because they significantly separated bleeders from non-bleeders, but in particular because of the striking finding that they actually varied, moving in the opposite direction, i.e. the index decreases in the group of bleeders as opposed to cirrhotics where it goes up, thus establishing an inverse relationship with portal pressure in this model of portal hypertension.

The congestion index was significantly smaller in the bleeders than in non-bleeders $(0.057$ vs 0.073$)$. When compared with MORIYASU et al. ${ }^{(23)}$ and HAAG et al. ${ }^{(11)}$ data on normal and cirrhotic subjects, we clearly see that hepatosplenic schistosomotic patients with a past history of hemorrhage present a congestion index in the opposite direction to the cirrhotic patients $(0.057$ vs 0.171$)$, while those without a history of hemorrhage have a congestion index similar to normal subjects $(0.073$ vs 0.070$)$ (Table 5).

Considering the physiopathologic differences in portal hemodynamics between cirrhotics and schistosomotics highlighted above, this finding is not at all surprising, since portal blood overflow is a well established alteration in hepatosplenic schistosomiasis as a result of increased splenic blood flow $^{(5,6,15,22,33)}$, thus pushing the CI down. As it is likely that patients, either cirrhotics or schistosomotics, bleed as a result of increased pressure in the portal system, this is indirect evidence of a direct relationship between splenoportal flow and portal pressure in this disease.

This becomes clearly understandable once the CI reflects the variation in resistance (diameter) and blood flow (flow velocity). In both groups the mean portal vein diameters were very similar
$(1.36 \mathrm{~cm}$ vs $1.37 \mathrm{~cm})$ resulting in similar resistance; the blood flow velocity was the component actually responsible for the congestion index variance.

By demonstrating that the group without past a history of variceal bleeding had an overall higher frequency of collateral circulation, which was not significant, and that only the presence of the splenorenal vein was significant, we can deduce that there is a physiological alternative escape to the overflow state in this group of patients protecting them against bleeding events.

These subjects also had a less marked increase in portal and splenic blood flow velocity, which is in accordance with lower portal pressure and no bleeding. By analogy, although in the opposite direction, the relationship between portal blood flow velocity and collateral circulation has been similarly shown in cirrhotics by different authors: bigger esophageal varices and the left gastric vein were associated with much lower portal blood flow velocities ${ }^{(7,11,21,31,35)}$. What seems clear, from a topographical perspective, is the important role played by the left gastric vein in portal hypertension physiology, draining blood to the stomach and esophagus and the splenorenal vein to the mesenteric plexus in order to maintain lower portal pressure.

More recently, LI et al. ${ }^{(16)}$ studying portal hemodynamics and their relationship with esophageal varices in patients with liver cirrhosis - before and after esophageal variceal bleeding episodes - showed that bleeding was closely related to the increased diameter $(>6 \mathrm{~mm})$ and hepatofugal high-flow velocity status $(>15 \mathrm{~cm} / \mathrm{s})$ in the left gastric vein (LGV). In this very well designed study, they found that those with an endoscopic finding of large variceal calipter (F3 size) had LGV with a mean diameter of $72 \mathrm{~mm}( \pm 0,24)$, a mean flow velocity of $16.0 \mathrm{~cm} / \mathrm{s}$ $( \pm 3,19)$ and $100 \%$ hepatofugal flow direction.

This is in accordance with the data available from angiography studies in schistosomotic patients that have been done since the early sixties (overflow regime). Considering that in the group of non-bleeders there were many more alternative routes (collateral vessels) for the overflow caused by the splenomegaly status, the increase in portal pressure is much less, thus leading to lower incidences of bleeding.

Apparently contradictory were the findings reported by SACERDOTI et al. ${ }^{(32)}$ : increased portal blood flow velocity associated with a much higher frequency of paraumbilical vein patency in cirrhotics with a poorer clinical score. However, this might be related to the fact that this collateral does not

TABLE 5. Congestion index trends in normal, schistossomotic and cirrhotic subjects

\begin{tabular}{|c|c|c|c|c|c|c|c|c|}
\hline & \multicolumn{2}{|c|}{$\begin{array}{c}\text { Hepatosplenic } \\
\text { schistosomiasis }\end{array}$} & \multicolumn{2}{|c|}{ Normal } & \multicolumn{2}{|c|}{ Cirrhosis } & & \\
\hline & with & without & & & & & & \\
\hline & hemorrhage & hemorrhage & Moriyasu & Haag & Moriyasu & Haag & & \\
\hline \multirow{3}{*}{ Congestion index of the portal vein } & & & & & & Child A & Child B & Child C \\
\hline & 0.057 & 0.073 & 0.070 & 0.070 & 0.171 & 0.170 & 0.200 & 0.250 \\
\hline & & & \pm 0.029 & \pm 0.015 & & & & \\
\hline
\end{tabular}


help blood escape as does the left gastric vein, esophageal varices and splenorenal veins, which deviate some flow from the portal vein to the inferior vein cava, thus decreasing the flow into the portal vein. In all likelihood the paraumbilical vein simply expands the circulatory space in response to increasing hepatic outflow resistance.

Our findings show, for the first time, the opposite behavior of CI in schistosomotic portal hypertension with a past history of bleeding when compared with cirrhotic patients. In addition, those without bleeding had a CI close to subjects with normal portal pressure as reported by MORIYASU et al. ${ }^{(23)}$ and HAAG et al. ${ }^{(11)}$ (Table 5).

Moreover, the finding of an inverse relation of the CI with portal pressure and bleeding in schistosomotics, as opposed to cirrhotics, may suggest that the CI could also be a useful tool in cases of mixed liver disease in identifying the predominant physiopathology component of the portal hypertension, thus helping in the decision whether to use splenectomy as part of the therapeutic management.

In conclusion, this study demonstrates that, in addition to the usefulness of Doppler duplex studies in order to identify the collateral circulation status and its interrelationship with splanchnic blood flow, congestion index and collateral circulation may also be useful predictors of variceal hemorrhage among patients with shistosomotic portal hypertension.

However, considering the close correlation between left gastric vein hemodynamic parameters and esophageal variceal size in cirrhotics with and without esophageal bleeding, it would appear that combining the data of endoscopic findings and Doppler ultrasound parameters seems to be the best approach in predicting the risk of esophageal variceal bleeding in schistosomiasis portal hypertension as well.

\section{ACKNOWLEDGMENTS}

I am particularly thankful to Dr Célia Fárias (in memoriam) for her leadership at the Postgraduate Division (Department of Internal Medicine - UFPE) and giving the best of her professional life in order to support all the research projects developed at that time. I also would like to thank my wife and colleague Almerinda Silva for her critical input.

Arruda SMB, Barreto VST, Amaral FJ. Dopplerfluxometria portal na esquistossomose hepatoesplênica com e sem antecedentes de hemorragia por varizes esofágicas. Arq Gastroenterol. 2008;45(1):11-6.

RESUMO - Racional - Hipertensão portal pré-sinusoidal com freqüentes episódios de hemorragia digestiva alta são aspectos característicos da esquistossomose hepatoesplênica, forma clínica que acomete cerca de $5 \%$ dos brasileiros com esquistossomose mansônica. Objetivo - Avaliar parâmetros ultra-sonográficos (modo-B e Doppler) nos hepatoesplênicos com e sem antecedentes de hemorragia digestiva. Métodos - Estudo descritivo-transversal com 27 pacientes consecutivos com esquistossomose hepatoesplênica: 12 com passado de hemorragia digestiva alta (média de idade de 48,7 anos - grupo I) e 12 sem antecedentes de hemorragia digestiva alta (média de idade de 44,7 anos - grupo II). Todos foram igualmente submetidos a testes laboratoriais e endoscopia digestiva alta. Foram excluídos os doentes com hepatopatia mista e/ou trombose (três casos) ou transformação cavernosa da veia porta. Resultados - O grupo I apresentou aumento significante da média de velocidade de fluxo na veia porta que o grupo II $(26.36 \mathrm{~cm} / \mathrm{s}$ vs $17.15 \mathrm{~cm} / \mathrm{s})$. Embora estatisticamente não significante considerando todos os tipos ( $100 \%$ vs $83 \%$ ), houve maior freqüência de circulação colateral do tipo esplenorenal no grupo II (67\% vs $17 \%)$, assim como o

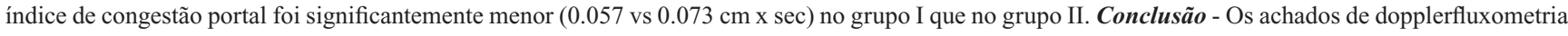
em esquistossomose hepatoesplênica sugerem que a hipertensão portal esquistossomótica é fortemente influenciada pelo hiperfluxo e a circulação colateral secundária exerce importante papel no equilíbrio hemodinâmico nestes pacientes.

DESCRITORES - Hipertensão portal. Esquistossomose mansoni. Ultra-sonografia Doppler. 


\section{REFERENCES}

1. Bolondi L, Gaiani S, Barbara L. Accuracy and reproducibility of portal vein flow measurement by Doppler ultrasound. J Hepatol. 1991;13:269-73.

2. Bonazza A, Moro E, Alessandrini P, Gravili S, Bittolo Bon G. Dynamic liver radionuclide scanning in the evaluation of liver function and portal hypertension in cirrhotic patients. J Nucl Biol Med. 1994;38:1-5.

3. Boyer TD. Portal hypertensive hemorrhage: pathogenesis and risk factors. Semin Gastrointest Dis. 1995;6:125-33.

4. Cioni G, Turrini F, Tincani E, D'Alimonte P, Cristani A, Boldrini E, Baraldi E, Pedrazzin PG, Ventura P, Ventura E. Prevention of a first episode of variceal bleeding: role of duplex Doppler sonographic measurement of the acute response to beta-blockers. J Ultrasound Med. 1999;18:633-8.

5. Coutinho A. Alterações hemodinâmicas na esquistossomose mansônica hepato-esplênica. J Bras Med. 1964;8:299-309.

6. Coutinho A. Hemodynamic studies of portal hypertension in schistosomiasis. Am J Med. 1968;44:547-56.

7. Dagradi AE. The natural history of esophageal varices in patients with alcoholic liver cirrhosis. An endoscopic and clinical study. Am J Gastroenterol. 1972;57:521-40.

8. de Vries PJ, Hoekstra JB, de Hooge P, van Hattum J. Portal venous flow and follow-up in patients with liver disease and healthy subjects. Assessment with duplex Doppler. Scand J Gastroenterol. 1994;29:172-7.

9. Domingues AL, Lima AR, Dias HS, Leão GC, Coutinho A. An ultrasonographic study of liver fibrosis in patients infected with Schistosoma mansoni in Northeast Brazil. Trans R Soc Trop Med Hyg. 1993;87:555-8.

10. Domingues AL, Barreto VS. Esquistossomose hepática. In: Sociedade Brasileira de Hepatologia. Compêndio de hepatologia. 2a ed. São Paulo, Fundo Editorial BYK; 2001. P.391-420.

11. Haag K, Rossle M, Ochs A, Huber M, Siegerstetter V, Olschewski M, Berger E, Lu $\mathrm{S}$, Blum HE. Correlation of duplex sonography findings and portal pressure in 375 patients with portal hypertension. AJR Am J Roentgenol. 1999;172:631-5.

12. Hatz C, Jenkins JM, Ali QM, Abdel-Wahab MF, Cerri GG, Tanner M. A review of the literature on the use of ultrasonography in shistosomiasis with special reference to its use in field studies. 2. Schistosoma mansoni. Acta Trop. 1992;51:15-28.

13. Iwao T, Toyonaga A, Ikegami M, Sumino M, Oho K, Shigemori H, Sakaki M, Nakayama M, Tanikawa K, Iwao J. Portal vein hemodynamics in cirrhotic patients with portal hypertensive gastropathy: an echo-Doppler study. Hepatogastroenterology. 1994;41:230-4.

14. Japanese Research Society for Portal Hypertension. The general rules for recording endoscopic findings on esophageal varices. Jpn J Surg. 1980;10:84-7.

15. Lacerda CM. Angiographic and pressoric alterations after splenectomy and internal ligation of esophageal varices on mansonic shitosomiasis [thesis]. São Paulo: Faculdade de Medicina da Universidade de São Paulo; 1991.

16. Li FH, Hao J, Xia JG, Li HL, Fang H. Hemodynamic analysis of esophageal varices in patients with liver cirrhosis using color Doppler ultrasound. World J Gastroenterol. 2005; 11:4560-5.

17. Lee SS, Hadengue A, Girod C, Braillon A, Lebrec D. Reduction of intrahepatic vascular space in the pathogenesis of portal hypertension. In vitro and vivo studies in the rat. Gastroenterology. 1987;93:157-61

18. Lomas DJ, Britton PD, Summerton CB, Seymour CA. Duplex Doppler measurement of portal vein in portal hypertension. Clin Radiol. 1993;48:311-5.

19. Marin PE, Plaza G, Barrios CC, Mune AA, Saez LR, Salamero JM. Metaplasia mieloide e hipertension portal. Rev Clin Esp. 1972;126:29-34.

20. Marin PE, Mirave JIA, Boixeda D, Ranz FH, Plaza G. El estudio hemodinamico del sistema porta en seis casos de metaplasia mieloide. Rev Clin Esp. 1977;145:271-3.
21. Medhat A, Iber FL, Dunne M, Baum R. Ultrasonographic findings with bleeding and non-bleeding esophageal varices. Am J Gastroenterol. 1988;83:58-63.

22. Mies S, Neto OB, Beer A Jr, Baia CE, Alfieri F Jr, Pereira LM, Sette MJ, Raia S Systemic and hepatic hemodynamics in hepatosplenic Manson's schistosomiasis with and without propranolol. Dig Dis Sci. 1997;42:751-61.

23. Moriyasu F, Nishida O, Ban N, Nakamura T, Sakai M, Miyake T, Uchino H. "Congestion Index" of the portal vein. AJR Am J Roentgenol. 1986;146:735-9.

24. Nelson RC, Lovett KE, Chezmar JL, Moyers JH, Torres WE, Murphy FB, Bernardino ME. Comparison of pulsed Doppler sonography and angiography in patients with portal hypertension. AJR Am J Roentgenol. 1987;149:77-81.

25. The North Italian Endoscopic Club for the Study and Treatment of Esophageal Varices Prediction of the first variceal hemorrhage in patients with cirrhosis of the liver and esophageal varices. A prospective multicenter stusdy. N Engl J Med. 1988;319:983-9.

26. Patriquin H, Lafortune M, Burns PN, Dauzat M. Duplex Doppler examination in portal hypertension: technique and anatomy. AJR Am J Roentgenol. 1987;149:71-6.

27. Pereira LM, Melo MC, Lacerda C, Spinelli V, Domingues AL, Massarolo P, Mies S, Saleh MG, McFarlane IG, Williams R. Hepatitis B virus infection in Schistosomiasis mansoni. J Med Virol. 1994;42:203-6.

28. Pereira LM, Melo MC, Saleh MG, Massarolo P, Koskinas J, Domingues AL, Spinell V, Mies S, Willians R, Mc Farlane IG. Hepatitis C virus infection in Schistosomiasis mansoni in Brazil. J Med Virol. 1995;45:423-8.

29. Piscaglia F, Donati G, Serra C, Muratori R, Solmi L, Gaiani S, Gramantieri L, Bolondi L. Value of splanchnic Doppler ultrasound in the diagnosis of portal hypertension. Ultrasound Med Biol. 2001;27:893-9.

30. Raia S, da Silva LC, Gayotto LC, Forster SC, Fukushima J, Strauss E. Portal hypertension in schistosomiasis: a long-term follow-up of a randomized trial comparing three types of surgery. Hepatology. 1994;20:398-403.

31. Ready JB, Robertson AD, Golf JS, Rector WG Jr. Assessment of the risk of bleeding from esophageal varices by continuos monitoring of portal pressure. Gastroenterology. 1991; 100:1403-10

32. Sacerdoti D, Bolognesi M, Bombonato G, Gatta A. Paraumbilical vein patency in cirrhosis: effects on hepatic hemodynamics evaluated by Doppler sonography. Hepatology. 1995;22:1689-94.

33. Sarin SK, Mosca P, Sabba C, Groszmann. Hyperdynamic circulation in a chronic murine schistosomiasis model of portal hypertension. Hepatology. 1991;13:581-4.

34. Schmassmann A, Zuber M, Livers M, Jager K, Jenzer HR, Fehr HF. Recurrent bleeding after variceal hemorrhage: predictive value of portal venous duplex sonography. AJR Am J Roentgenol. 1993;160:41-7.

35. Siringo S, Bolondi L, Gaiani S, Sofia S, Di Febo G, Zironi G, Rigamonti A, Miglioli M, Cavalli G, Barbara L. The relationship of endoscopy, portal Doppler ultrasound flowmetry, and clinical and biochemical tests in cirrhosis. J Hepatol. 1994;20:11-8.

36. Siringo S, Bolondi L, Gaiani S, Sofia S, Zironi G, Rigamonti A, Di Febo G, Miglioli M, Cavalli G, Barbara L. Timing of the first variceal hemorrhage in cirrhotic patients: prospective evaluation of Doppler flowmetry, endoscopy and clinical parameters. Hepatology. 1994;20:66-73.

37. Sullivan A, Rheinlander H, Weintraub L. Esophageal varices in agnogenic myeloid metaplasia: desappearance after splenectomy. Gastroenterology. 1974;66:429-32.

38. Tatsu JP, Rocher L, Péletier G, Kuoch V, Kulh E, Miquel A, Buffet C, Bléry M. Hepatic venus pressure gradients mesured by duplex ultrasound. Clin Radiol. 2002;57:746-52.

39. World Health Organization. Meeting on ultrasonography in schistosomiasis. UNDP/World Bank/Special program for research and training in tropical disease. Cairo, Egypt. 1-4 October 1991. 